\title{
Social responsibility disclosure by South African industrial holding companies: a research note
}

\section{C de Villiers}

Department of Accounting and Finance, University of Pretoria

Received: December 1998

SAJAR

Revised: August 1999

Vol 14 no. 1

Accepted: June 2000

The disclosure of social responsibility in the 1982, 1987, 1992 and 1997 annual reports of ten companies listed in the industrial holdings section of the Johannesburg Stock Exchange was analysed. Information on employee-related matters is disclosed most often, followed by community-related information and environment-related information. Descriptive statements (as opposed to monetary or quantitative non-monetary disclosures) predominate, as does good news (as opposed to bad news or neutral disclosures). Disclosures increased over the years, with a dramatic increase from 1992 to 1997.

\section{KEY WORDS}

Social responsibility disclosure, social disclosure, social reporting, social accounting, environmental reporting.

\section{Contact}

Charl de Villiers, Department of Accounting and Finance, University of Pretoria, Pretoria 0002, Republic of South Africa. Email: cdeville@hakuna.up.ac.za.

\section{INTRODUCTION AND THE RESEARCH PROBLEM}

Social reporting appears to be on the increase in many countries around the world (Gray Kouhy \& Lavers, 1995; Deegan \& Gordon, 1996; Mathews, 1997; De Villiers $\&$ Visser, 1998). Social reporting encompasses reporting on and for the environment, energy, products/customers, the community and employees (Hackston \& Milne, 1996). In the developed world, legislation requires increased levels of social disclosure, but a large (and increasing) volume of information is published on a voluntary basis (Gray Kouhy \& Lavers, 1995:60-61). In countries such as New 
Zealand (Hackston \& Milne, 1996:86) and South Africa, legislation requires the disclosure of very little social information. Nevertheless, social disclosures are often made in these countries (Hackston \& Milne, 1996:88; Bogiages \& Vorster, 1993:53; De Villiers, 1997a:51; De Villiers 1997b:49). Many reasons have been suggested for this phenomenon. One of the popular suggestions is that it could be in the pursuit of organisational legitimacy. The notion of legitimacy posits, in brief, that an organisation can only continue to thrive, and indeed exist, if its aims and methods are compatible with those of society. Social reporting is a method employed by organisations to demonstrate the compatibility of their aims and methods with those of society (Lindblom, 1994).

The principal question to be answered in this paper is whether there has been an increase in social reporting in South Africa. A second aim is to identify the areas of social reporting that appear to be most popular in South Africa.

\section{PRIOR RESEARCH IN SOUTH AFRICA}

The Unit for Social Accounting was established in the Department of Accounting at the University of Pretoria in 1993 (De Villiers \& Visser, 1998:15). Research reports are published annually (Bogiages \& Vorster, 1993; Steyn \& Vorster, 1994; Steyn \& Vorster, 1995; De Villiers, 1997a; De Villiers, 1997b) and a database is maintained. The Unit concentrates on environmental and employee-related disclosures in annual reports. According to these research reports, environmental disclosure in annual reports is increasing, but it is not yet at the level of disclosure by corporations in the developed world (De Villiers, 1997b:48,49). Employee disclosure is also increasing, albeit at a slower pace than environmental disclosure (De Villiers, 1997a:51). Employee reporting in South Africa has not been compared with similar reporting in other countries.

Related research in South Africa has concentrated on standard setting for environmental disclosure (De Villiers, 1996), environmental disclosure in specific sectors (Doppegieter \& De Villiers, 1996) and the measurement of stakeholder attitudes towards environmental reporting (De Villiers, 1998). These studies reveal that some sectors disclose much more environmental information than other sectors and that South African corporate stakeholders are very positively disposed towards environmental reporting.

No South African research on other categories of social disclosure other than employee-related and environmental disclosures could be found. Examples of other categories of social disclosure are community-related information, information on products/consumers and information on energy usage (Hackston \& Milne, 1996). 


\section{THE NOTION OF LEGITIMACY}

According to Lindblom (1994:2), the concept of legitimacy was developed in political science for the purpose of applying it to political institutions. Its use was later extended to all organisations, and specifically to corporations.

Shocker \& Sethi (1974:67) explain the concept as follows:

"Any social institution - and business is no exception - operates in society via a social contract, expressed or implied, whereby its survival and growth are based on:

1. The delivery of some socially desirable ends to society in general, and

2. The distribution of economic, social, or political benefits to groups from which it derives its power.

In a dynamic society, neither the sources of institutional power nor the needs for its services are permanent. Therefore, an institution must constantly meet twin tests of legitimacy and relevance by demonstrating that society requires its services and that the groups benefiting from its rewards have society's approval."

The concept of legitimacy implies that corporations will only change their behaviour or disclosure practices if they experience pressure to do so. The pressure will be exerted in the form of indications by society that the corporation's aims and methods are not in line with those of society. Therefore, the greater the pressure of this kind that a corporation experiences, the more social information it will disclose.

Recent social and political developments in South Africa have been quite astonishing. Individuals and groups that had seemingly irreconcilable differences have collectively created a new, equitable political dispensation, which for the first time in the history of the country includes its entire population. During this process, long-held beliefs and value systems were reconsidered and often discarded. This questioning attitude is being experienced as traumatic by some segments of society, because it is in stark contrast with the rule-based and unquestioning attitude that prevailed in the previous era.

One of the things that is being questioned is the role that corporations fulfil in society. Although the ANC, the ruling party, has proved itself to be an adherent of capitalist ideals, the rhetoric of its leaders sometimes reflects their anti-capitalist links. The questioning attitude and the socialist rhetoric can be construed as pressure on corporations and a threat to their legitimacy. Under these circumstances it might have been expected that social reporting would have increased substantially from 1992 with the unbanning of the ANC and the negotiations on a new dispensation and 
intensified during and after the first free and fair general elections in 1994. Of course, other changes such as globalisation, pressure from foreign client companies, domestic public pressure, new legislation, the new constitution and enlightened management also played a major role and continue to do so.

\section{METHOD}

The survey was limited to companies listed on the Johannesburg Stock Exchange (JSE) in the industrial holdings sector. Industrial holdings sector companies have subsidiaries that cover most of the other sectors on the JSE. In other words, these companies represent a spread of activities in various fields.

It was decided to collect data from annual reports only and to analyse the reports for the years 1982, 1987, 1992 and 1997 to enable comparisons over time to be made. The number of companies chosen, was limited to 10 in order to restrict the analyses to a manageable level. This resulted in the analysis of 40 annual reports (four annual reports for each of 10 companies). The survey included the 10 companies with the highest market capitalisation in the industrial holdings sector of the JSE in 1997. Companies not listed on the JSE since 1982 were discarded from the list and replaced by the next biggest companies ${ }^{1}$. The listing was not in all cases included in the industrial holdings sector from 1982.

The number of companies listed under industrial holdings varied from 47 in 1982 to 51 in 1997. The 10 companies included in the survey represented $43.7 \%$ of the market capitalisation of the industrial holdings sector in 1997.

The method of analysis chosen, was the one used and comprehensively described by Hackston \& Milne (1996). This method was chosen to facilitate comparison with other surveys. The social categories used by Hackston \& Milne are, for example, the same as those used by Gray, Kouhy \& Lavers (1995). The authors also provide a detailed description of the method in their paper. It includes an exhaustive checklist of disclosure items under each category of social disclosure. This checklist is an invaluable tool for the researcher who attempts to evaluate disclosures objectively and was used in this study.

Annual reports were scrutinised for the frequency and nature of social disclosures. The measure of volume used, was the number of sentences. In the financial statements one line item was regarded as one sentence. Each sentence was classified in three different ways. Firstly, the category of social disclosure (for example environment-related); secondly, whether the disclosure is monetary, quantitative but

\footnotetext{
${ }^{1}$ The companies were: Amic, Barlows, Bidvest (previously Currie Motors), Charter, CG Smith, Lonrho, Plate Glass, Rembrandt Beherend, Remgro, and Tegkor. 
non-monetary or declarative; and thirdly, whether the disclosure is good news, bad news or neutral.

For the purpose of the first classification (for example environment-related. etc.) the checklist was used. For the second classification, it was considered that a sentence may combine more than one of the three categories. In such cases, the first of the three categories, in the order above, that applied to the particular sentence was used. This was done in order to categorise sentences in the "highest order" category it qualifies for. For the purposes of the third classification, the disclosure was evaluated from the perspective of the stakeholder to which it refers or that may be interested in the information, and then it was decided whether the disclosure represented good, bad or neutral news.

\section{RESULTS OF THE SURVEY}

The main results of the survey are contained in Table 1.

Table 1: Social responsibility disclosures (SRD) in number of sentences (total for ten companies)

\begin{tabular}{lrrrr}
\hline & $\mathbf{1 9 8 2}$ & $\mathbf{1 9 8 7}$ & $\mathbf{1 9 9 2}$ & $\mathbf{1 9 9 7}$ \\
Environment & 5 & 32 & 40 & 134 \\
Energy & 0 & 0 & 0 & 0 \\
Products/consumers & 10 & 20 & 27 & 39 \\
Community & 13 & 30 & 77 & 245 \\
Employee (health and safety) & 0 & 3 & 0 & 47 \\
Employee (other) & 210 & 278 & 264 & 426 \\
General & 0 & 0 & 0 & 6 \\
Total & $\mathbf{2 3 8}$ & $\mathbf{3 6 3}$ & $\mathbf{4 0 8}$ & $\mathbf{8 9 7}$ \\
& & & & \\
Monetary & & & & 120 \\
Non-monetary & 32 & 63 & 65 & 112 \\
Declarative & 57 & 75 & 89 & 665 \\
Total & 149 & 225 & 254 & $\mathbf{8 9 7}$ \\
& $\mathbf{2 3 8}$ & $\mathbf{3 6 3}$ & $\mathbf{4 0 8}$ & \\
Good news & & & & 87 \\
Bad news & & & & 67 \\
Neutral & 174 & 260 & 308 & $\mathbf{8 9 7}$ \\
Total & 15 & 45 & 51 & 49 \\
\end{tabular}

The total number of social disclosure sentences contained in the annual reports of the ten companies increased from 238 in 1982 to 897 in 1997. This represents an increase of $277 \%$. The five-yearly increases were respectively $53 \%$ (from 1982 to 1987 ), $12 \%$ 
(from 1987 to 1992) and 120\% (from 1992 to 1997). The largest percentage increase therefore occurred in the last five-year period. This result was expected, given the change in the social climate that prevailed in South Africa during the nineties. The results also indicate a large percentage of change, albeit from a lower base, in the period between 1982 and 1987. The category that contributed most to this increase was "employee(other)" which has 68 more sentences, followed by the category "environment" which has 27 more sentences. "Employee (other)" is a category that includes all the employee information other than the information pertaining to health and safety. The labour movement began to assert itself in South Africa during the eighties and this trend could have contributed to the increase. The increase in the disclosure of environmental information can be ascribed entirely to the disclosures of one of the ten companies, which at that stage was involved in asbestos-related lawsuits.

The data clearly indicate that, by 1997 , the three most popular categories of social reporting were "employee(other)", "community" and "environment". These three categories accounted for $90 \%$ of the volume of social reporting in the 1997 annual reports. In 1982, one category, namely "employee(other)" accounted for $88 \%$ of all social reporting. Community and environmental disclosures were at a very low level.

The social disclosure sentences identified were also categorised in terms of whether they constituted monetary; quantitative but non-monetary; or declarative information. An example of quantitative but non-monetary information is the disclosure of the number of employees in the company. Declarative information was the most common form of disclosure, accounting for between $62 \%$ and $63 \%$ of the total number of sentences disclosed in 1982, 1987 and 1992. The proportion of declarative information increased to $74 \%$ in 1997. Therefore, whereas the total volume of disclosure increased by $120 \%$ between 1992 and 1997, the declarative type of disclosure increased by $162 \%$. Non-monetary information increased steadily (by $32 \%, 19 \%$ and $26 \%$ in the five-year intervals) and monetary information almost doubled in both the first and the last periods and remained relatively constant in the middle period. The overwhelming emphasis, and increase in emphasis, on declarative information is both understandable and disappointing. It is understandable, because it is much easier for companies to make general statements than to ascribe figures to social endeavours. And it is disappointing, because once monetary or non-monetary figures are mentioned, it is much easier for the user of the report to form an idea of how pervasive the actions or the plans are. The next stage in the development of the social reporting agenda should be the improvement of the quality of reporting, by among other things the inclusion of more figures, and not merely the volume of reported material.

In the classification of sentences on social disclosure into good news, bad news and neutral statements, it was not surprising to find that good news predominated. The percentage of good news was $73 \%$ in $1982,72 \%$ in $1987,75 \%$ in 1992 and $89 \%$ in 
1997. The good news disclosed did not only increase dramatically in number of sentences, but the percentage of all disclosure that constituted good news had also increased. In contrast, the number of sentences containing bad news actually diminished by half from 1992 to 1997. This reduction is disappointing. Admission of things that have gone wrong is the first step towards the correction of the mistakes, and a statement of that nature lends credibility to a company's stated aims regarding future improvement.

Figure 1 clearly illustrates an upward trend in the volume of the three most common types of social reporting by South African industrial holding companies. The graph indicates a gradual increase up to 1992 and a dramatic rise thereafter.

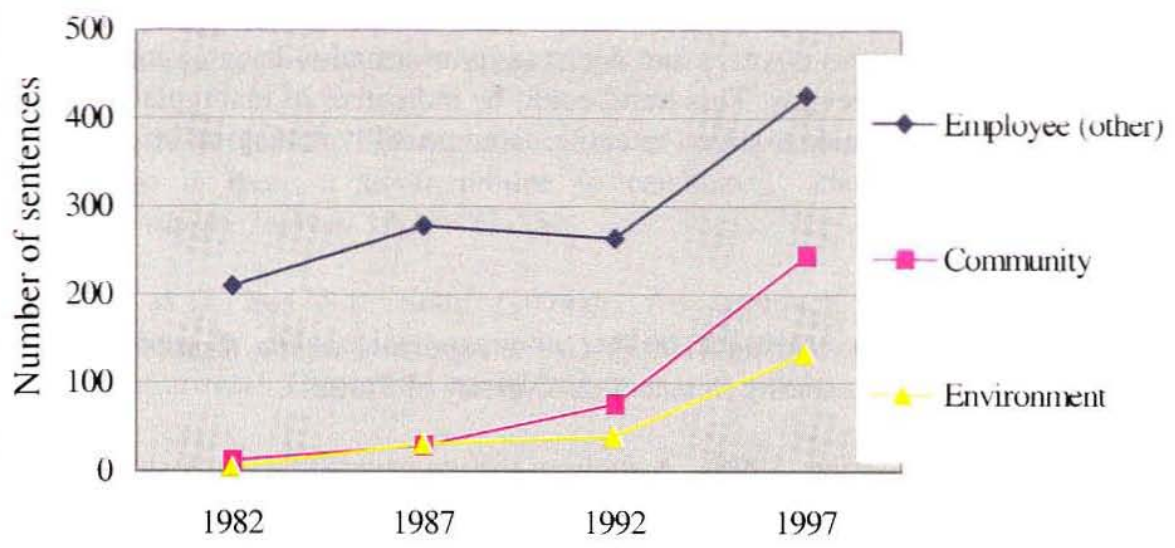

Figure 1: Social disclosure by 10 industrial holding companies

\section{CONCLUSIONS}

The small sample size and the exclusion of companies other than industrial holding companies make it impossible to generalise the conclusions to all South African companies. Further research to establish disclosure practices in different industries may be useful in this regard.

However, we can conclude that the volume of social disclosure by South African industrial holding companies is increasing over time. The gradual increase up to 
1992 turned into a dramatic increase between 1992 and 1997. However, it was not only the volume that increased; the number of companies that disclosed social information also increased from 1982 to 1997. In 1982, 9 of the 10 companies in the survey disclosed social information, but by 1997 all of them did. Community and environment issues were only addressed respectively by five and four companies in 1982, whereas all 10 companies disclosed such information in 1997.

The increase in social disclosure is consistent with the notion of legitimacy. Recent changes in the political environment may have contributed to the pressure on companies to report social information as part of their legitimation efforts.

The most popular areas of social disclosure are "employee(other)", "community" and "environment" information, in that order. These are also the most popular areas of voluntary social disclosure in the UK (Gray, Kouhy \& Lavers, 1995).

There was a preponderance of declarative (over quantitative information) and of positive (over negative and neutral information) in social disclosure in annual reports. The emphasis on positive and declarative information became more marked over the period under review. This trend could be indicative of manipulation tactics, i.e. an effort by companies to divert attention from possibly damaging information to other more positive issues.

\section{REFERENCES}

Bogiages, G.H. and Q. Vorster (1993). Green reporting in the Republic of South Africa, School of Accounting Sciences, University of Pretoria.

Deegan, C. and B. Gordon (1996). A study of the environmental disclosure practices of Australian corporations. Accounting and Business Research, 26(3):187-199.

De Villiers, C.J. (1996). Towards a corporate environmental reporting standard. Meditari, 39-60.

De Villiers, C.J. (1997a). Employee reporting in South Africa. $4^{\text {th }}$ Edition. Department of Accounting, University of Pretoria, Pretoria.

De Villiers, C.J. (1997b). Green reporting in South Africa. $4^{\text {th }}$ Edition. Department of Accounting, University of Pretoria, Pretoria.

De Villiers, C.J. (1998). The willingness of South Africans to support more green reporting, South African Journal of Economic and Management Sciences, NS 1(1):145-167. 
De Villiers, C.J. and W. Visser (1998). Survey of Environmental Reporting in South Africa. $5^{\text {th }}$ Edition. KPMG and Department of Accounting, University of Pretoria, Johannesburg.

Doppegieter, J.J. and C.J. de Villiers (1996), Environmental reporting practices in the South African energy sector, Management Dynamics, 5(1):15-42.

Gray, R., Kouhy, R. and S. Lavers (1995). Corporate social and environmental reporting: A review of the literature and a longitudinal study of UK disclosure, Accounting, Auditing and Accountability Journal, 8(2), 47-77.

Hackston, D. and M.J. Milne (1996). Some determinants of social and environmental disclosures in New Zealand companies, Accounting, Auditing and Accountability Journal, 9(1):77-108.

Lindblom, C.K. (1994). The implications of organizational legitimacy for corporate social performance and disclosure. Paper presented at the Critical Perspectives on Accounting Conference, New York, N.Y.

Mathews, M.R. (1997). Twenty-five years of social and environmental accounting research: Is there a silver jubilee to celebrate?, Accounting, Auditing and Accountability Journal 10(4):481-531.

Shocker, A.D. and S.P. Sethi (1974). An approach to incorporating social preferences in developing corporate action strategies., Sethi S.P. (Ed.), The unstable ground: Corporate social policy in a dynamic society, Melville, CA, 6780.

Steyn, J.O. and Q. Vorster (1994). Green reporting in the Republic of South Africa. $2^{\text {nd }}$ Edition. Department of Accounting, University of Pretoria, Pretoria.

Steyn, J.O. and Q. Vorster (1995). Employee reporting in the Republic of South Africa. 2nd Edition. Department of Accounting, University of Pretoria, Pretoria. 